\author{
Abstracta Iranica \\ Abstracta Iranica Revue bibliographique pour le domaine irano-aryen \\ Volume 34-35-36 | 2017 \\ Comptes rendus des publications de 2011-2013
}

\title{
Parvin Mahmoudveysi, Denise Bailey. The Gorani language of Zarda, a village of West Iran.
}

Thomas Jügel

\section{(2) OpenEdition \\ 12 Journals}

Electronic version

URL: http://journals.openedition.org/abstractairanica/41149

DOI: 10.4000/abstractairanica.41149

ISSN: 1961-960X

Publisher:

CNRS (UMR 7528 Mondes iraniens et indiens), Éditions de l'IFRI

\section{Electronic reference}

Thomas Jügel, « Parvin Mahmoudveysi, Denise Bailey. The Gorani language of Zarda, a village of West Iran. », Abstracta Iranica [Online], Volume 34-35-36 | 2017, document 4, Online since 15 July 2016, connection on 02 October 2020. URL : http://journals.openedition.org/abstractairanica/41149; DOI : https://doi.org/10.4000/abstractairanica.41149

This text was automatically generated on 2 October 2020 .

Tous droits réservés 


\title{
Parvin Mahmoudveysi, Denise Bailey. The Gorani language of Zarda, a village of West Iran.
}

\author{
Thomas Jügel
}

\section{REFERENCES}

Parvin Mahmoudveysi, Denise Bailey. The Gorani language of Zarda, a village of West Iran. Wiesbaden, Reichert, 2013, xiii + 218 p. (Beiträge zur Iranistik 37)

1 Both books are the results of the DoBeS project "Documentation of Gorani, an endangered language of West Iran" from 2007 to 2012. They represent descriptions of two similar dialects of a highly endangered language the authors call 'Gorani' (simply called 'Kurdish' by the speakers) and which show close connections to Hawrami and heavy influence from Sorani and so-called 'Southern Kurdish' (I. K. Fattah, Les dialectes kurdes méridionaux, 2000, (Acta Iranica 37)).

2 The transcribed texts together with the recordings, which are published on a CD that one finds at the inner side of the back board, represent the core of both books. The sound files can be copied, which makes them most useful for further studies. In addition, the collected texts form an interesting part of the study on their own (e.g. life stories, customs) and offer a rich amount of data for discourse analysis.

3 The text corpus is preceded by a detailed grammatical survey that focuses on morphology with several comments on phonology and syntax. In case of need, elicited data is used to complete the grammatical description. However, the authors point to many open questions that remain. A lexicon concludes each book, including a plenty examples in the publication from 2012.

4 These two Gorani varieties represent interesting examples of languages in transition. Basic morphology and many lexemes display their closeness to Hawrami. However, their morphological structure (e.g. tense formation) or alignment systems are very 
similar if not identical with Sorani or 'Southern Kurdish'. Case and gender distinction is on the brink of oblivion. The variety of Zarda seems to be the more conservative one. They also show peculiar progressive formations, passivisation and resultative forms. For a detailed discussion confer this author's review, to appear in Iran and the Causasus. The authors have set a new standard of language documentation and their works will hopefully serve as a model for many studies to come.

6 Ce compte rendu concerne également un autre ouvrage ( $\left(\mathrm{R}^{2}-\mathrm{N}^{\circ} 3\right)$ :

7 Parvin Mahmoudveysi, Denise Bailey, Ludwig Paul, and Geoffrey Haig, The Gorani language of Gawrajū, a village of West Iran. Wiesbaden, Reichert, 2012, xi+276 p. (Beiträge zur Iranistik 35)

\section{AUTHORS}

THOMAS JÜGEL

Mondes iranien et indien, Paris 